\title{
Perception of Pupils, on Home Grown School Feeding Programme in Ebonyi State, South-East Nigeria
}

\author{
Jonathan Ogbonna Igboji ${ }^{1}$, Prince Christian Ifeanachor Umoke ${ }^{2}$, MaryJoy Umoke ${ }^{3}$ Augustine Alugbala \\ Nwazunku ${ }^{3}$, Chioma Adaora Nwalieji ${ }^{3}$, Emmanuel Uchechukwu Umoke ${ }^{1}$, Rosemary N. Onwe ${ }^{1}$, \\ Emmanuel Ifeanyi Nwafor ${ }^{4} \&$ Clara Nneka Nwalieji ${ }^{4}$ \\ ${ }^{1}$ Ebonyi state University Abakaliki, Nigeria \\ ${ }^{2}$ Department of Human Kinetics and Health Education, University of Nigeria, Nsukka, Nigeria \\ ${ }^{3}$ Ebonyi State Ministry of Health Abakaliki, Nigeria \\ ${ }^{4}$ Alex-Ekwueme Federal University Teaching Hospital Abakaliki, Ebonyi state, Nigeria \\ Correspondence: MaryJoy Umoke, Ebonyi State Ministry of Health Abakaliki, Nigeria. Tel: 234- 806-232-5890. \\ E-mail: maryjoy4umoke@gmail.com
}

Received: June 12, 2020 Accepted: July 17, 2020 Online Published: July 26, 2020

doi:10.5539/gjhs.v12n10p45 URL: https://doi.org/10.5539/gjhs.v12n10p45

\begin{abstract}
The purpose of the study was to determine the perception of pupils on the Home Grown School Feeding Programme in Ebonyi State, South-East Nigeria. The research utilized a cross-sectional survey research design on a population of 66591 pupils in the selected public primary schools. A sample of 540 pupils was used for the study. The instrument for data collection is a 30-item "Questionnaire on Perception of Pupils on Home Grown School Feeding Programme (QPPHGSFP)." Four hundred and eighty-six (486) copies of each questionnaire were administered and 483 (99.4\%) were retrieved. Data were analyzed using frequencies and percentages. Chi-square statistic was used to test the null hypothesis at a $\mathrm{p} \leq 0.05$ level of significance. Result showed that HGSFP makes the pupils to enroll, attend, remain in school. Pupils like the quality and the size of the food served, and it was locally produced. Age, sex, and class level was not significant $(\mathrm{p}>0.05)$ while the location was significant $(\mathrm{p}<0.05)$. Conclusively pupils' perception was good on HGSFP. We recommend that the government and other stakeholders in charge of the programme should remain committed to providing the needed resources for the smooth running of the programme to improve the educational infrastructure of rural communities.
\end{abstract}

Keywords: HGSFP, perception, pupils, socio-demography

\section{Introduction}

School feeding programme (SFP) according to World Bank is a targeted social safety nets that provide both educational and health benefits to the most vulnerable children, thereby increasing enrollment and attendance rates, reducing absenteeism, increasing cognitive development and improving food security at the household level (World Food Programme, 2015). Generally, the objectives for the school meals are mainly three; School feeding as a social safety net; as a requirement to advance learning and educational outcomes; and to boost nutrition and or health status of the school children (Aliyar, Gelli, \& Hamdani 2015; Bashir, Lockheed, Ninan \& Tan, 2018). School feeding programme attract children to school by providing nutritious meals in exchange for school participation. If children are malnourished, SFP may also boost learning and cognitive development by improving attention spans and nutrition. The attraction of these programme is their potential to improve both school participation, learning, and cognitive outcomes (Azubuike \& Mbah, 2019).

Home Grown School Feeding Programme (HGSFP) can be seen as a vehicle to stimulate local economies by providing a market and source of income for local smallholder farmers (Gelli, Masset, Folso, Kusi, Arhinful, Asante, et al., 2016; Bundy, de Silva, Horton, Jamison \& Patton, 2018a). Also, it can be used as a strategy to ensure that School feeding menus contain a variety of nutritious food that school children are accustomed to (Aliyar, Gelli, \& Hamdani, 2015; Bundy, de Silva, Horton, Jamison \& Patton 2018b). Besides, the school feeding programme (SFPs) is intended to alleviate short-term hunger, improve nutrition and cognition of children and transfer income to families (Cole, 2013).

While schools in countries under high and upper-middle-income have access to food for all school children, those 
nations under-middle and low-income, have limited or no access to food provision in schools (Yendaw and Dayour, 2015). For instance, nearly half the world's schoolchildren, some 310 million, in low- and middle-income countries eat a daily meal at school. India now feeds more than 100 million children; Brazil 48 million; China 44 million; South Africa and Nigeria each more than 9 million (WFP, 2019).

However, in the U.S., the National School Lunch Program (NSLP) is the second-largest nutrition assistance program subsidizing over 30 million meals each school day at a Federal cost of $\$ 14$ billion annually (US Department of Agriculture Food and Nutrition Service, 2018). However, in Nigeria, the National Home Grown School Feeding Programme (NHGSFP) is a feeding programme that aims to improve the health and educational outcomes of public primary school pupils at the cost of N70 per day (NHGSFP, 2017). It uses farm produce locally grown by smallholder farmers to provide children nutritious mid-day meals on every school day (Drake, Woolnough, Burbano, \& Bundy, 2016). The programme links local farmers to the education sector by facilitating their access to the school feeding market (NHGSFP, 2017) and support incomes of caterers and cooks involved in the foodservice provision (Gelli, Masset, Folson, Kusi, Arhinful, Asante, et al., 2016; World Food Programme, 2019).

It has been observed that factors such as hunger, illness, frequent truancy, lack of school requirements among others are the causes of poor enrollment and high dropout rates in schools (Kristjansson, Francis, Liberato, Benkhalti Jandu, Welch et al., 2012). Nevertheless, in regions where School feeding programme is functioning well, analysts have seen consistent positive effects of school feeding in its different modalities on energy intake, micronutrient status, school enrollment, and attendance of the children participating in SFPs compared to non-participants (World Bank, 2012; Kristiansson, Gelli, Welch, Greenhalgh, Liberato, Francis \& Espejo, 2016). Studies have also indicated that the effective provision of food enhances school children participation. For instance, in the studies of Taylor and Ogbuogu, (2016) and Bundy et al., (2018b) pupils reported that the school feeding program contributes to their enrollment, attendance, and participation in primary schools. Also, Nikiema, 2017 found that take-home rations (THRs) increased school attendance for both boys and girls. however, the findings further showed that girls' enrolment rate within schools increased by 3.2 percent which was driven by the increase in the number of newly enrolled girls compared with boys.

Moreover, most of the studies conducted on Home Grown School Feeding Programme were done outside Nigeria and other parts of the country. There has not been any conducted in Ebonyi State to the best of the researchers' knowledge. This deficiency created the gap which the present study intended to fill.

\subsection{Objective of the Study}

To determine the perception of pupils on the Home Grown School Feeding Programme (HGSFP), based on age, sex, class, and location.

\subsection{Significance of the Study}

Findings from the study will assist in recommending the most effective strategy for implementing a result-oriented School Feeding programme in Ebonyi State of Nigeria. Intended beneficiaries (school children and families) will benefit maximally from the programme as a result of the implementation of recommendations from this work. Furthermore, stakeholders will be well informed on the relevance or otherwise of the SFP on primary education. Positive outcomes will get them committed to the success and sustenance of the programme. Also, the negative effects of the programme if found will be addressed.

\subsection{Scope of the Study}

The study will cover a total of 54 public primary schools from 7 LGAs (2 LGAs per senatorial zone) in Ebonyi State. This translates to $5 \%$ of schools from each of the 7 LGAs. The research is limited to the perception of pupils, on Home Grown School Feeding Program among primary school children in Ebonyi State.

\subsection{Research Questions}

1. What is the perception of pupils on the Home Grown School Feeding Programme (HGSFP) based on age, sex, class, and location?

\subsection{Research Hypotheses}

The following hypotheses will be specifically tested at $\mathrm{p} \leq 0.05$ level of significance.

1. There is no significant difference in the pupils' perception of the school feeding programme based on age

2. There is no significant difference in the pupils' perception of the school feeding programme based on sex

3. There is no significant difference in the pupils' perception of the school feeding programme based on class level 
4. There is no significant in the pupils' perception of the school feeding programme based on location

\subsection{Theoretical Framework}

\section{Gregory's theory of perception}

One of the most widely held constructivist theories of perception is Gregory's theory who used the flow of ontogenetic time (Gregory, 1990). Gregory established mechanisms for the explanation of impressions and reasons why our perception is so complex and universal. One of the greatest advantages of his approach is that when speaking of the process of perception it takes into account our personal history and that he understood that to operate with sensory data does not necessarily mean to perceive, but to perceive always means to integrate feelings into a broader context of our beliefs and opinions. It also involves also active participation of higher cognitive functions responsible for constructing. The brain has to guess what an individual sees based on previous experiences (McLeod, 2018). This theory is suitable for this work because, based on the past experience of pupils that received food in the course of HGSFP, they will have to integrate their feelings and say their opinion.

\section{Methods}

\subsection{Research Design}

A descriptive, cross-sectional research design was used for this study.

\subsection{Setting of Study}

This study took place in 7 purposively selected LGAs in Ebonyi State, Southeast Nigeria.

\subsection{Study Population}

The population comprised 1066 public primary schools in the state practicing HGFSP. The population of pupils is 317, 087 (Ebonyi State Universal Basic Education Board, 2018).

\subsection{Sampling and Sampling Technique}

The sample size of the study is 486 pupils, in Fifty-four (54) Public Primary Schools, which is $5 \%$ of public Primary Schools, in Ebonyi State. A multistage sampling technique was used. This procedure involved first dividing the state into zones: Ebonyi North, Ebonyi Central, and Ebonyi South. secondly, purposive sampling was used to select the seven Local Government where the study was carried out, North-2, Central-2, and South-3 that are currently providing school meals (In-school), thirdly selection of schools in different LGAs and lastly, nine (9) pupils ( 3 in primary 1,2, and 3 respectively) were randomly selected.

\subsection{Instruments for Data Collection}

A self- administered questionnaire was used to obtain information about school feeding from pupil. It consists of thirty (30) items in 2 Sections. Section A has 5 items on demographic data and section B has 25 items on the school feeding programme in the school. The face validity of the instrument was validated by two other experts and the reliability established from the result of two schools in Ebonyi State that is not included in the study. A high-reliability co-efficient of 0.934 was obtained hence, the instrument was considered reliable for use in this study.

\subsection{Method of Data Collection}

The researchers had meeting with the school headteachers who were used as research assistants. The procedure for data collection was explained and their consent obtained. The teachers explained the content of the questionnaire to the pupils. Data was retrieved from each school on agreed dates by the researchers. A total of four hundred and eighty-six (486) was distributed and 483 (99.4\%) retrieved.

\subsection{Method of Data Analysis}

Data generated were analyzed using SPSS Version 23. Descriptive statistics such as frequency, percentages, and chi-square were employed and hypotheses tested at $\mathrm{p} \leq 0.05$ level of significance.

\section{Inclusion criteria}

Schools currently providing school meals (In-school) for the past six months.

\section{Exclusion criteria}

Schools not currently providing school meals (In-school).

\subsection{Ethical Consideration}

Ethical review and approval was obtained from the Ethical Committee of the State Ministries of Education and 
Health.

\section{Results}

\subsection{Socio-Demographic Characteristics of Respondents}

A total of 483 pupils completed the questionnaire, out of which 254 (52.6\%) were males, and 229(47.4\%) were females. The age of the respondents was ranged between 4-13 years. distribution their age distribution was as follows: 146 (30.2\%) were age 4-6 years, 253 (52.4\%) 7-9 years, and 84(17.4\%) 10-13years with the mean age of 7.6 +0.48 SD. Based on classes, $179(37.1 \%)$ were in primary 1, 157(32.5\%) primary 2 and 147(30.4\%) primary 3. Concerning location, the majority of the pupils were living in the rural $321(66.5 \%)$ while less were in the urban 162(33.5\%). (Table 1)

Table 1. Socio-demographic characteristics of respondents $(n=483)$

\begin{tabular}{lll}
\hline Variable & Frequency & Percentage \\
\hline Age in years & 146 & 30.2 \\
$4-6$ & 253 & 52.4 \\
$7-9$ & 84 & 17.4 \\
$10-13$ & & \\
\hline Mean age: $\mathbf{7 . 6} \pm \mathbf{0 . 4 8 , \text { Min-Max: 4-13 }}$ & & \\
Sex & 254 & 52.6 \\
Male & 229 & 47.4 \\
Female & & 37.1 \\
\hline Class & 179 & 32.5 \\
Primary 1 & 157 & 30.4 \\
Primary 2 & 147 & \\
Primary 3 & & 33.5 \\
\hline Location & 162 & $\mathbf{1 0 0 . 0}$ \\
Urban & 321 & $\mathbf{4 8 3}$ \\
Rural & & \\
Total & & \\
\hline
\end{tabular}

\subsection{Pupils Perception of Home Grown School Feeding Programme}

The result of the study in table 2 revealed that the majority of the pupils $96.9 \%$ like HGSFP which showed good perception; 49.1\% come to school with snack money before the introduction of HGSFP, while after the introduction of HGSFP, $20.3 \%$ come to school with snack money. Moreover, $89.9 \%$ of participates do better in class due to HGSFP. On attendance, retention, and enrollment, $76.8 \%$ of the pupils attend school every day, $85.1 \%$ remain in school till school dismisses, $88.6 \%$ come to school regularly, $73.1 \%$ tell other children to come to their school. In addition, majority of pupils were served with local foods such as yam porridge 470(97.3), rice 481(99.6), beans porridge 473 (97.9), okpa 464(96.1) and moi-moi 425(88.0) while, eggs 221(45.8), fruit 117(24.2), meat 87(18.0), fish 201(41.6), garri and soup 51(10.6), were served in smaller quantities. Only few students received zobo drink 21(4.3), buns 23(4.8), chin chin 9(1.9), and biscuit14(2.9) and noodles 13(2.7). (Table 2) 
Table 2. Frequency and percentage of responses of pupils on their perception on HGSFP $(n=483)$

\begin{tabular}{|c|c|c|c|}
\hline $\mathbf{S} / \mathbf{N}$ & items & $\begin{array}{l}\text { Yes } \\
f(\%)\end{array}$ & $\begin{array}{l}\text { No } \\
f(\%)\end{array}$ \\
\hline 1. & Like the Home Grown School Feeding Programme (HGSFP)? & $468(96.9)$ & $15(3.1)$ \\
\hline 2. & Come to school with snack's money before the HGSFP? & 237(49.1) & $246(50.9)$ \\
\hline 3. & Come to school with snack's money after HGSFP? & $98(20.3)$ & $385(79.7)$ \\
\hline 4. & Food given to you is delicious and you like it? & $446(92.3)$ & $37(7.7)$ \\
\hline 5. & Satisfied with the size of food given to you? & $342(70.8)$ & 141(29.2) \\
\hline 6. & Attend school every day because of the food? & $371(76.8)$ & $112(23.2)$ \\
\hline 7. & Remain in school till school dismisses because of the food? & $411(85.1)$ & 72(14.9) \\
\hline 8. & Food helps you participate and understand better in class? & 434(89.9) & $49(10.1)$ \\
\hline 9. & Food makes pupils in your class to come to school? & $428(88.6)$ & $55(11.4)$ \\
\hline 10. & Tell other children to come to your school because of the food given? & $353(73.1)$ & 130(26.9) \\
\hline 11. & Served with food such as; Yam porridge & $470(97.3)$ & $13(2.7)$ \\
\hline 12. & Rice & $481(99.6)$ & $2(0.4)$ \\
\hline 13. & Beans porridge & $473(97.9)$ & $10(2.1)$ \\
\hline 14. & Okpa & $464(96.1)$ & $19(3.9)$ \\
\hline 15. & Moi-moi & $425(88.0)$ & $58(12.0)$ \\
\hline 16. & Eggs & $221(45.8)$ & $262(54.2)$ \\
\hline 17. & Fruits & $117(24.2)$ & $366(75.8)$ \\
\hline 18. & Meat & $87(18.0)$ & $396(82.0)$ \\
\hline 19. & Fish & 201(41.6) & $282(58.4)$ \\
\hline 20. & Garri and soup & $51(10.6)$ & $432(89.4)$ \\
\hline 21. & Zobo drink & $21(4.3)$ & $462(95.7)$ \\
\hline 22. & Buns & $23(4.8)$ & $460(95.2)$ \\
\hline 23. & Biscuits & $9(1.9)$ & $474(98.1)$ \\
\hline 24. & Chin-chin & $14(2.9)$ & $469(97.1)$ \\
\hline 25. & Noodles & $13(2.7)$ & $470(97.3)$ \\
\hline
\end{tabular}

\subsection{Pupils Perception and Socio-Demographic Determinants}

\section{Age}

We employed the Chi-square test and detected a statistically significant association between sociodemographic characteristics and perception. The good perception observed in this study was more among pupils within age 7-9 years (middle aged), however, there was no statistically significant association between the perception of pupils and age $(\mathrm{p}>0.05)$ in all the items. Though age was significant with pupils' perception on attendance $\left(\mathrm{p}=0.021^{*}\right)$, enrollment $\left(0.000^{*}\right)$ and Biscuit meal $\left(0.028^{*}\right)$. (Table 3$)$

\section{Sex}

The good perception observed in this study was found more among male pupils than females however, there was no statistically significant association between the perception of pupils and sex ( $>0.05)$. (Table 4).

\section{Class level}

The study also revealed that there was no statistically significant association between the perception of pupils and class level( $p>0.05)$. Nevertheless, pupils in primary one had a more positive perception than the other groups. (Table 5) 


\section{Location}

Fifteen out of twenty-five items on perception were statistically significant with location $(p \leq 0.05)$ with those in the rural having a good perception more than those in the urban. These were on their perception of: size of food given $\left(\mathrm{p}=0.007^{*}\right)$; attendance $\left(0.005^{*}\right)$; class participation $\left(0.036^{*}\right)$, enrollment $\left(0.004^{*}, 0.001^{*}\right)$. Then on food served: yam $\left(0.009^{*}\right)$; moi-moi $(0.002)$; eggs $\left(0.00^{*}\right)$; fruit $\left(0.00^{*}\right)$; meat $(0.005)$; fish $\left(0.026^{*}\right)$; Garri and soup $\left(0.011^{*}\right)$ and zobo drink $\left(0.017^{*}\right)$. (Table 6$)$

Table 3. Frequency, Percentage and Chi-square of Responses of pupils on their Perception of HGSFP based on age $(\mathrm{n}=483)$

\begin{tabular}{|c|c|c|c|c|c|c|}
\hline \multirow{3}{*}{$\mathbf{S} / \mathbf{n}$} & \multirow{3}{*}{ Items } & 4-6 years & $\begin{array}{l}\text { Ages } \\
7-9 \text { years }\end{array}$ & 10-13years & \multirow{3}{*}{$\chi^{2}$ cal } & \multirow{3}{*}{ p-value } \\
\hline & & Yes & Yes & Yes & & \\
\hline & & $f(\%)$ & $f(\%)$ & $f(\%)$ & & \\
\hline 1. & $\begin{array}{l}\text { Like the Home Grown School Feeding Programme } \\
\text { (HGSFP)? }\end{array}$ & $145(31.0)$ & 243(51.9) & $80(17.1)$ & 4.212 & 0.122 \\
\hline 2. & $\begin{array}{l}\text { Come to school with snack's money before the } \\
\text { HGSFP? }\end{array}$ & 79(33.3) & $122(51.5)$ & $36(15.2)$ & 2.854 & 0.240 \\
\hline 3. & Come to school with snack's money after HGSFP? & $27(27.6)$ & $52(53.1)$ & 19(19.4) & 0.584 & 0.747 \\
\hline 4. & Food given to you is delicious and you like it? & $139(31.2)$ & $233(52.2)$ & $74(16.6)$ & 3.856 & 0.145 \\
\hline 5. & Satisfied with the size of food given to you? & 104(30.4) & 181(52.9) & $57(16.7)$ & 0.432 & 0.806 \\
\hline 6. & Attend school every day because of the food? & $124(33.4)$ & $186(50.1)$ & $61(16.4)$ & 7.775 & $0.021 *$ \\
\hline 7. & $\begin{array}{l}\text { Remain in school till school dismisses because of the } \\
\text { food? }\end{array}$ & 130(31.6) & $206(50.1)$ & $75(18.2)$ & 5.645 & 0.059 \\
\hline 8. & $\begin{array}{l}\text { Food helps you participate and understand better in } \\
\text { class? }\end{array}$ & 134(30.9) & $225(51.8)$ & $75(17.3)$ & 0.860 & 0.651 \\
\hline 9. & Food makes pupils in your class to come to school? & $137(32.0)$ & $219(51.2)$ & $(72(16.8)$ & 5.702 & 0.058 \\
\hline 10. & $\begin{array}{l}\text { Tell other children to come to your school because of } \\
\text { the food given? }\end{array}$ & 124(35.1) & $164(46.5)$ & $65(18.4)$ & 19.986 & $0.000^{*}$ \\
\hline 11. & Served with food such as; Yam porridge & $143(30.4)$ & 244(51.9) & $83(17.7)$ & 1.673 & 0.433 \\
\hline 12. & Rice & $146(30.4)$ & $252(52.4)$ & $83(17.2)$ & 1.837 & 0.399 \\
\hline 13. & Beans porridge & $143(30.2)$ & $247(52)$. & $83(17.5)$ & 0.434 & 0.805 \\
\hline 14. & Okpa & $140(30.2)$ & $245(52.8)$ & $79(17.0)$ & 1.316 & 0.518 \\
\hline 15. & Moi-moi & $128(30.1)$ & $223(52.5)$ & 74(17.4) & 0.200 & 0.990 \\
\hline 16. & Eggs & $62(28.1)$ & $122(55.2)$ & $37(16.7)$ & 1.355 & 0.508 \\
\hline 17. & Fruits & $31(26.5)$ & $65(55.6)$ & 21(17.9) & 1.036 & 0.508 \\
\hline 18. & Meat & $25(28.7)$ & $47(54.0)$ & $15(17.2)$ & 0.134 & 0.935 \\
\hline 19. & Fish & 63(31.3 & $106(52.7)$ & $32(15.9)$ & 0.578 & 0.749 \\
\hline 20. & Garri and soup & $14(27.5)$ & $24(47.1)$ & $13(25.5)$ & 2.604 & 0.272 \\
\hline 21. & Zobo drink & $8(38.1)$ & $8(38.1)$ & $5(23.8)$ & 1.825 & 0.402 \\
\hline 22. & Buns & $9(39.1)$ & $10(43.5)$ & $4(17.4)$ & 0.999 & 0.607 \\
\hline 23. & Biscuits & $6(66.7)$ & $1(11.1)$ & $2(22.2)$ & 7.133 & $0.028^{*}$ \\
\hline 24. & Chin-chin & $7(50.0)$ & $4(28.6)$ & $3(21.4)$ & 3.560 & 0.169 \\
\hline 25. & Noodles & $6(46.2)$ & $4(30.8)$ & $3(23.0)$ & 2.561 & 0.278 \\
\hline
\end{tabular}


Table 4. Frequency, Percentage and Chi-square of responses of pupils on their Perception of HGSFP based on Sex $\mathrm{n}=(483)$

\begin{tabular}{|c|c|c|c|c|c|}
\hline \multirow[b]{2}{*}{$\mathbf{S} / \mathbf{N}$} & \multirow[b]{2}{*}{ Items } & \multicolumn{2}{|l|}{ Sex } & \multirow[b]{2}{*}{$\chi^{2}$ cal } & \multirow[b]{2}{*}{ p-value } \\
\hline & & $\begin{array}{l}\text { Male } \\
\text { Yes } \\
f(\%)\end{array}$ & $\begin{array}{l}\text { Female } \\
\text { Yes } \\
f(\%)\end{array}$ & & \\
\hline 1. & Like the Home Grown School Feeding Programme (HGSFP)? & $248(53.0)$ & $220(47.0)$ & 0.984 & 0.321 \\
\hline 2. & Come to school with snack's money before the HGSFP? & $124(52.3)$ & $113(47.7)$ & 0.013 & 0.908 \\
\hline 3. & Come to school with snack's money after HGSFP? & $54(55.1)$ & $44(44.9)$ & 0.321 & 0.577 \\
\hline 4. & Food given to you is delicious and you like it? & $240(53.8)$ & $206(46.2)$ & 3.496 & 0.061 \\
\hline 5. & Satisfied with the size of food given to you? & $183(53.5)$ & $159(46.5)$ & 0.398 & 0.528 \\
\hline 6. & Attend school every day because of the food? & $203(54.7)$ & $168(46.5)$ & 2.909 & 0.880 \\
\hline 7. & Remain in school till school dismisses because of the food? & $215(52.3)$ & 196(47.7) & 0.085 & 0.771 \\
\hline 8. & Food helps you participate and understand better in class? & $233(53.7)$ & 201(46.3) & 2.071 & 0.150 \\
\hline 9. & Food makes pupils in your class to come to school? & $228(53.3)$ & $200(46.7)$ & 0.703 & 0.402 \\
\hline 10. & Tell other children to come to your school because of the food given? & 192(54.4) & 161(45.6) & 1.710 & 0.191 \\
\hline 11. & Served with food such as; Yam porridge & $248(52.4)$ & $229(47.6)$ & 0.222 & 0.638 \\
\hline 12. & Rice & $252(52.4)$ & $229(47.6)$ & 1.811 & 0.178 \\
\hline 13. & Beans porridge & $250(52.9)$ & $223(47.1)$ & 0.649 & 0.420 \\
\hline 14. & Okpa & $246(53.0)$ & $218(47.0)$ & 0.872 & 0.350 \\
\hline 15. & Moi-moi & $224(52.7)$ & $201(47.3)$ & 0.020 & 0.888 \\
\hline 16. & Eggs & $106(48.0)$ & $115(52.0)$ & 3.494 & 0.062 \\
\hline 17. & Fruits & $59(50.4)$ & $58(49.6)$ & 0.289 & 0.594 \\
\hline 18. & Meat & $47(54.0)$ & $40(46.0)$ & 0.088 & 0.767 \\
\hline 19. & Fish & $105(52.2)$ & $96(47.8)$ & 0.017 & 0.897 \\
\hline 20. & Garri and soup & $29(56.9)$ & $22(43.1)$ & 0.418 & 0.518 \\
\hline 21. & Zobo drink & $11(52.4)$ & $10(47.6)$ & 0.000 & 0.984 \\
\hline 22. & Buns & $11(47.8)$ & $12(52.2)$ & 0.220 & 0.639 \\
\hline 23. & Biscuits & $5(55.6)$ & $4(44.4)$ & 0.032 & 0.857 \\
\hline 24. & Chin-chin & $7(50.0)$ & $7(50.0)$ & 0.039 & 0.844 \\
\hline 25. & Noodles & $7(53.8)$ & $6(46.2)$ & 0.008 & 0.927 \\
\hline
\end{tabular}


Table 5. Frequencies, Percentage and Chi-square of responses of pupils on their Perception HGSFP based on class levels $\mathrm{n}=483$

\begin{tabular}{|c|c|c|c|c|c|c|}
\hline \multirow{4}{*}{$\mathbf{S} / \mathbf{N}$} & \multirow{4}{*}{ Items } & \multicolumn{3}{|c|}{ Class levels } & \multirow{4}{*}{$\chi^{2}$ cal } & \multirow{4}{*}{ p-value } \\
\hline & & \multirow{3}{*}{$\begin{array}{l}\text { Primary } \\
1 \\
\text { Yes } \\
f(\%)\end{array}$} & \multirow{3}{*}{$\begin{array}{l}\text { Primary } \\
2 \\
\text { Yes } \\
f(\%)\end{array}$} & \multirow{3}{*}{$\begin{array}{l}\text { Primary } \\
3 \\
\text { Yes } \\
f(\%)\end{array}$} & & \\
\hline & & & & & & \\
\hline & & & & & & \\
\hline 1. & $\begin{array}{l}\text { Like the Home Grown School Feeding Programme } \\
\text { (HGSFP)? }\end{array}$ & 37.2 & 32.3 & 30.6 & 0.398 & 0.820 \\
\hline 2. & Come to school with snack's money before the HGSFP? & 38.8 & 28.7 & 32.5 & 3.115 & 0.211 \\
\hline 3. & Come to school with snack's money after HGSFP? & 35.7 & 37.8 & 26.5 & 1.718 & 0.424 \\
\hline 4. & Food given to you is delicious and you like it? & 38.3 & 32.3 & 29.4 & 4.822 & 0.900 \\
\hline 5. & Satisfied with the size of food given to you? & 38.9 & 32.1 & 28.4 & 2.732 & 0.255 \\
\hline 6. & Attend school every day because of the food? & 38.8 & 32.1 & 29.1 & 2.341 & 0.310 \\
\hline 7. & Remain in school till school dismisses because of the food? & 37.5 & 32.1 & 30.4 & 0.253 & 0.881 \\
\hline 8. & Food helps you participate and understand better in class? & 37.8 & 33.4 & 28.8 & 5.438 & 0.066 \\
\hline 9. & Food makes pupils in your class to come to school? & 38.3 & 32.7 & 29.0 & 4.290 & 0.117 \\
\hline 10. & $\begin{array}{l}\text { Tell other children to come to your school because of the } \\
\text { food given? }\end{array}$ & 39.4 & 31.2 & 29.5 & 3.036 & 0.219 \\
\hline 11. & Served with food such as; Yam porridge & 36.8 & 32.3 & 30.9 & 1.438 & 0.487 \\
\hline 12. & Rice & 37.2 & 32.2 & 30.6 & 4.170 & 0.124 \\
\hline 13. & Beans porridge & 37.2 & 31.7 & 31.1 & 7.662 & 0.220 \\
\hline 14. & Okpa & 37.3 & 32.3 & 30.4 & 0.283 & 0.868 \\
\hline 15. & Moi-moi & 36.2 & 32.2 & 31.5 & 2.122 & 0.346 \\
\hline 16. & Eggs & 35.7 & 32.1 & 32.1 & 0.591 & 0.744 \\
\hline 17. & Fruits & 35.9 & 32.5 & 31.6 & 0.128 & 0.938 \\
\hline 18. & Meat & 42.5 & 33.3 & 24.1 & 2.261 & 0.323 \\
\hline 19. & Fish & 38.3 & 33.3 & 28.4 & 0.705 & 0.703 \\
\hline 20. & Garri and soup & 45.1 & 25.5 & 29.4 & 1.877 & 0.391 \\
\hline 21. & Zobo drink & 38.1 & 23.8 & 38.1 & 0.940 & 0.625 \\
\hline 22. & Buns & 39.1 & 34.8 & 26.1 & 0.216 & 0.897 \\
\hline 23. & Biscuits & 66.7 & 0.0 & 33.3 & 5.175 & 0.75 \\
\hline 24. & Chin-chin & 50.0 & 21.4 & 28.6 & 1.212 & 0.546 \\
\hline 25. & Noodles & 46.2 & 23.1 & 30.8 & 0.664 & 0.718 \\
\hline
\end{tabular}


Table 6. Frequency, Percentage and Chi-square of responses of pupils on their Perception of HGSFP based on Location $(\mathrm{n}=483)$

\begin{tabular}{|c|c|c|c|c|c|}
\hline \multirow[b]{2}{*}{$\mathbf{S} / \mathbf{N}$} & \multirow[b]{2}{*}{ Items } & \multicolumn{3}{|l|}{ Location } & \multirow[b]{2}{*}{ p-value } \\
\hline & & $\begin{array}{l}\text { Urban } \\
\text { Yes } \\
f(\%)\end{array}$ & $\begin{array}{l}\text { Rural } \\
\text { Yes } \\
f(\%)\end{array}$ & $\chi^{2}$ cal & \\
\hline 1. & Like the Home Grown School Feeding Programme (HGSFP)? & $158(33.8)$ & $310(66.2)$ & 0.328 & 0.567 \\
\hline 2. & Come to school with snack's money before the HGSFP? & $81(34.2)$ & $156(65.8)$ & 0.085 & 0.771 \\
\hline 3. & Come to school with snack's money after HGSFP? & 39(39.8) & $59(60.2)$ & 2.158 & 0.142 \\
\hline 4. & Food given to you is delicious and you like it? & $150(33.6)$ & $296(66.4)$ & 0.022 & 0.882 \\
\hline 5. & Satisfied with the size of food given to you? & $102(30.2)$ & $240(70.2)$ & 7.257 & $0.007^{*}$ \\
\hline 6. & Attend school every day because of the food? & $112(30.2)$ & $259(69.8)$ & 8.063 & $0.005^{*}$ \\
\hline 7. & Remain in school till school dismisses because of the food? & $132(32.1)$ & $279(67.9)$ & 2.507 & 0.113 \\
\hline 8. & Food helps you participate and understand better in class? & $139(32.0)$ & $295(68.0)$ & 4.392 & $0.036^{*}$ \\
\hline 9. & Food makes pupils in your class to come to school? & $134(31.3)$ & 294(68.7) & 8.400 & $0.004 *$ \\
\hline 10. & Tell other children to come to your school because of the food given? & $103(29.2)$ & $250(70.8)$ & 11.194 & $0.001 *$ \\
\hline 11. & Served with food such as; Yam porridge & $162(34.5)$ & $308(65.5)$ & 6.742 & $0.009^{*}$ \\
\hline 12. & Rice & $161(35.5)$ & $320(66.5)$ & 0.244 & 0.621 \\
\hline 13. & Beans porridge & $159(33.6)$ & $314(66.4)$ & 0.057 & 0.811 \\
\hline 14. & Okpa & $157(33.8)$ & $307(66.2)$ & 0.463 & 0.496 \\
\hline 15. & Moi-moi & $132(31.1)$ & 293(68.9) & 9.778 & $0.002 *$ \\
\hline 16. & Eggs & 41(18.6) & $180(81.4)$ & 41.060 & $0.000 *$ \\
\hline 17. & Fruits & 13(11.1) & 104(88.9) & 34.846 & $0.000 *$ \\
\hline 18. & Meat & $18(20.7)$ & 69(79.3) & 7.861 & $0.005^{*}$ \\
\hline 19. & Fish & $56(27.9)$ & $145(72.1)$ & 4.982 & $0.026^{*}$ \\
\hline 20. & Garri and soup & $9(17.6)$ & $42(82.4)$ & 6.462 & $0.011^{*}$ \\
\hline 21. & Zobo drink & $2(9.5)$ & 19(90.5) & 5.681 & $0.017^{*}$ \\
\hline 22. & Buns & $7(30.4)$ & $16(69.6)$ & 0.104 & 0.747 \\
\hline 23. & Biscuits & $4(44.4)$ & $5(55.6)$ & 0.489 & 0.484 \\
\hline 24. & Chin-chin & $1(7.1)$ & 13(92.9) & 4.507 & $0.034^{*}$ \\
\hline 25. & Noodles & $1(7.7)$ & $12(92.3)$ & 4.004 & $0.045^{*}$ \\
\hline
\end{tabular}

\section{Discussion}

\subsection{Pupils perception of Home Grown School Feeding Programme}

The result of the study revealed that the majority of the pupils $96.9 \%$ like HGSFP which showed a good perception; $49.1 \%$ come to school with snack money before the introduction of HGSFP, while after the introduction of HGSFP, $20.3 \%$ come to school with snack money, which is in line with World Bank, (2012), Day, Sahota, Christian \& Cocks, (2015), Gelli et al, 2016 who stated that the programme indirectly impacts the economic and social lives of pupils and their families which is one of the rationales of HGSFP. On the quality and quantity of food, $92.3 \%$ like the quality of food, and $70.8 \%$ are satisfied with the size of food given. This finding was supported by Ngussa, \& Twarira (2020) who reported that pupils viewed food served as enough and delicious. In contrast, Yendaw \& Dayour, (2015); and Mensah (2016) reported that pupils viewed meals prepared for them were not served on time, moderately low quality, and not sufficient.

Furthermore, $89.9 \%$ of participants perceived they do better in class due to HGSFP which agrees with Alderman Gilligan, \& Lehrer (2010); Yunusa, (2012), Just, (2014), Stuber, (2014), Muiru, Thinguri, Njagi \& Kiarie (2014); 
Hussien, Ibrahim, \& Hassanin (2015); Ngussa, and Mbifile (2016); Anderson Gallagher, \& Ritchie (2017); Nyakundi (2017); World Food Programme (2017); Bashir Lockheed, Ninan, \& Tan (2018); Maijo (2019); Azubuike \& Mbah, (2019); and Mwendwa, \& Gori (2019) whose studies revealed that school feeding program has a significant influence on school participation, effectiveness in learning and cognitive outcomes. In contrast, Michelmore, \& Dynarski (2017) found no influence learning activities of pupils.

On attendance, retention, and enrollment, $76.8 \%$ of the pupils perceived they attend school every day, $85.1 \%$ remain in school till school dismisses, $88.6 \%$ come to school regularly, $73.1 \%$ tell other children to come to their school. This is similar to the findings of the World Food Programme (2010); Jomaa, McDonnell \& Probart, (2011); Osei- Fosu, (2011); Uwameiye and Salami. (2013); Dei (2014); Stuber, (2014); Mkanyika (2014), Yendaw and dayour, (2015); Snilstveit, Stevenson, Phillips, Vojtkova, and Gallagher (2015); Chaula (2015); Gelli (2015); Sanya (2015); Uwameiye, (2016); Taylor \& Ogbogu, (2016); Kristiansson et al. (2016); WFP (2016); Nyakundi (2017); Ibrahim, (2017); Milledzi, Keney \& Amponsah (2017); Mahama, (2017); Serebour, (2017); Phiri \& Chisala (2017); Reuben (2017); Lee, (2018); Gyasi, Asante, Adans, \& Antwi- Boasiako, (2018); Konzabre, (2018); Tagoe, (2018); Salifu, Boateng, and Kunduzore (2018); Aurino, Tranchant, Diallo, and Gelli (2018); Bundy et al. (2018); Maijo (2018); Snilstveit et al. (2018); Mwendwa, \& Gori (2019); Azubuike and Mbah, (2019); and Kilu and Mugambi (2019) who reported levels of increase in enrolment and attendance, retention promote retention, reducing absenteeism and dropouts, and improving learning outcomes among primary schools pupils.

The study also showed that pupils were served with local foods such as yam, rice, bean porridge, etc. this is in line with Devereux, Hochfeld, Karriem, Mensah, Morahanye, Msimango, Mukubonda, Naicker, Nkomo, Sanders, Sanousi, (2018) and Sitao, (2018) who reported that most products used were grown locally and will improve the income of farmers in the areas. However, even though pupils perceived food as being delicious, the food served pupils were not balanced as the majority reported they were not given eggs, meat, fish, and fruits. In other words, the school food menu need to incorporate appropriate and balance meals for school children. Zobo drink, buns, biscuits chin-chin, and noodles were not supposed to be given to the children as they were not in the meal plan of the Nigeria School Feeding Programme.

\subsection{Pupils Perception and Socio-Demographic Determinants}

Based on age, the good perception observed in this study was more among pupils within age 7-9 years (middle-aged), however, there was no statistically significant association between the perception of pupils and age $(\mathrm{p}>0.05)$ in all the items. Though age was significant with pupils' perception of attendance $\left(\mathrm{p}=0.021^{*}\right)$, enrollment $\left(0.000^{*}\right)$ and Biscuit meal $\left(0.028^{*}\right)$. This is in agreement with the result of Bukari \& Hajara (2015) who revealed that enrolments showed positive significant correlations $(\mathrm{p}<0.05)$ with age.

Furthermore, the good perception observed in this study was found more among male pupils than females however, there was no statistically significant association between the perception of pupils and sex $(\mathrm{p}>0.05)$. This is at variance with the result of Day, et al. (2015), Hussein, et al., (2015) who stated that girls were more satisfied than boys.

The study also revealed that there was no statistically significant association between the perception of pupils and class level( $(\mathrm{p}>0.05)$. Nevertheless, pupils in primary one had a more positive perception than the other groups. This is opposite to the findings of Day, et al., (2015), who stated that pupils from higher class seemed to perceive their school meals generally healthy.

Based on location, fifteen out of twenty-five items on perception were statistically significant with location ( $\mathrm{p} \leq$ 0.05 ) with those in the rural having a good perception more than those in the urban. These were on their perception of: size of food given $\left(\mathrm{p}=0.007^{*}\right)$; attendance $\left(0.005^{*}\right)$; class participation $\left(0.036^{*}\right)$, enrollment $\left(0.004^{*}, 0.001^{*}\right)$. Then on food served: yam $\left(0.009^{*}\right)$; moi-moi $(0.002)$; eggs $\left(0.00^{*}\right)$; fruit $\left(0.00^{*}\right)$; meat $(0.005)$; fish $\left(0.026^{*}\right)$; Garri and soup $\left(0.011^{*}\right)$ and zobo drink $\left(0.017^{*}\right)$. This assertion is at variance with the findings of Lagbo, (2012) who revealed that the urban school had more children enrolled than the rural community school.

In other words, the hypotheses of no significant difference in perception based on age, sex and class level were accepted. While that of location was rejected in this study.

However, there were some limitations in the study which include, time consumption, and difficulties in understanding the questionnaire. However, they were assisted by the teachers' interpretation of the content in their local language where necessary.

\section{Conclusion}

Conclusively, pupils' perception of HGSFP was good on enrollment, attendance, retention dropout, class 
participation, quality, and size of food though not a balanced diet. Food served was locally procured. Their age, sex, and class level was not significant with their perception of HGSFP while location was significant. Also, the were served locally grown food. We recommend that the government and other stakeholders in charge of the programme should remain committed to providing the needed resources for the smooth running of the programme to improve the educational infrastructure of rural communities. The school should explore further avenues to promote the active involvement of parents, communities, and local authorities in the development and implementation of the school feeding programme. The school should further enhance its agricultural activities and the school garden as an integral part of the school feeding programme.

\section{Competing Interests Statement}

The authors declare that there are no competing or potential conflicts of interest.

\section{References}

Alderman, H., Gilligan, D., \& Lehrer, K. (2010). The impact of food for education programs on school participation in Northern Uganda. International Food Policy Research Institute, Washington, DC.

Aliyar, R., Gelli, A., \& Hamdani, S. H. (2015). A Review of Nutritional Guidelines and Menu Compositions for School Feeding Programs in 12 Countries. Frontiers in public health, 3, 148. https://doi.org/10.3389/fpubh.2015.00148

Anderson, M. L., Gallagher, J., \& Ritchie, E. R. (2017). School Lunch Quality and Academic Performance. NBER Working Papers 23218, National Bureau of Economic Research, Inc.

Aurino, E., Tranchant, JP., Diallo, A.S., \& Gelli, A. (2018). School Feeding or General Food Distribution? Quasi-Experimental Evidence on the Educational Impacts of Emergency Food Assistance during Conflict in Mali. UNICEF Office of Research | Innocenti Working PaperWP-2018-04 | June 2018.

Azubuike, O. C., \& Mbah, P. E. (2019). Challenges of Child Nutrition: An Analysis of School Feeding Programmes (SFP) in South Eastern Nigeria. Savanna Journal of Basic and Applied Sciences, 1(1), 104-110. Retrieved from http://www.sjbas.com.ng

Bashir, S., Lockheed, M., Ninan, E., \& Tan, J. P. (2018). Facing Forward: Schooling for Learning in Africa (pp. 127-133). Washington, DC: AFD \& World Bank. Retrieved from https://openknowledge.worldbank.org/handle/10986/29377

Bukari, M., \& Hajara, I. P. (2015). The Ghana School Feeding Program: Factors Affecting Enrolment of Pupils in Garu-Tempane District, Upper East Region. International journal of innovative research and development, 4(1). Retrieved from www.ijird.com

Bundy, D. A. P., de Silva, N., Horton, S., Jamison, D. T., \& Patton, G. C. (2018a). Re-Imagining School Feeding: A High-Return Investment in Human Capital and Local Economies. Disease Control Priorities 3, v. 8. Washington, DC: World Bank. License: Creative Commons Attribution CC BY 3.0 IGO. Retrieved from http://dcp-3.org/sites/default/files/resources/CAHD_eBook.pdf

Bundy, D. A. P., de Silva, N., Horton, S., Jamison, D. T., \& Patton, G. C. (2018b). Optimizing Education Outcomes: High-Return Investments in School Health for Increased Participation and Learning. Disease Control Priorities, 3, v. 8. Washington, DC: World Bank. Retrieved from https://www.globalpartnership.org/sites/default/files/2018-04-gpe-optimizing-education-outcomes.pdf

Chaula, E. M. (2015). An assessment on influence of School Feeding Program on pupils' enrolment, attendance and academic performance in primary schools in Njombe district, Tanzania. Unpublished Master Dissertation. The Open University of Tanzania. Retrieved from http://repository.out.co.tz/Chaula- Dissertation

Cole, R. (2013). Community participation and Successful school feeding programmes in Southern Nigeria. UNIPRESS: Ibadan.

Day, R. E., Sahota, P., Christian, M. S., \& Cocks, K. (2015). A qualitative study exploring pupil and school staff perceptions of school meal provision in England. The British journal of nutrition, 114(9), 1504-1514. https://doi.org/10.1017/S0007114515002834

Dei, A. P. (2014). An Evaluation of the School Feeding Programme: A Case Study of Magong Primary Schools, Master Dissertation, UNISA. Retrieved from http://uir.unisa.ac.za/bistream/handle/10500/18779/dissertation_dei_fa.pdf?sequence=1\&isAllowed=y

Devereux, S., Hochfeld, T., Karriem, A., Mensah, C., Morahanye, M., Msimango, T., Mukubonda, A., Naicker, S., 
Nkomo, G., Sanders, D., \& Sanousi, M. (2018). "School Feeding in South Africa: What we know, what we don't know, what we need to know, what we need to do" Food Security SA Working Paper Series No. 004. DST-NRF Centre of Excellence in Food Security, South Africa.

Drake, L., Woolnough, A., Burbano, C., \& Bundy, D. A. P. (2016). Global school feeding sourcebook: lessons from 14 countries (English). Washington, D.C.: World Bank Group. http://documents.worldbank.org/curated/en/764611468197374242/Global-school-feeding-sourcebook-lesso ns-from-14-countries

Ebonyi State Universal Basic Education Board. (2018). Ebonyi State Universal Basic Education Board, Abakaliki Basic Education Statistics 2016/2017.

Gelli, A. (2015). School Feeding and Girls' Enrollment: The Effects of Alternative Implementation Modalities in Low-Income Settings in Sub-Saharan Africa. Frontiers in public health, 3, 76. https://doi.org/10.3389/fpubh.2015.00076

Gelli, A., Masset, E., Folson, G., Kusi, A., Arhinful, D. K., Asante, F., ... \& Drake, L. (2016). Evaluation of alternative school feeding models on nutrition, education, agriculture and other social outcomes in Ghana: rationale, randomised design and baseline data. Trials, 17, 37. https://doi.org/10.1186/s13063-015-1116-0

Gregory, R. L. (1990). Eye and Brain. The Psychology of Seeing. Oxford: Oxford University Press. Retrieved from https://sofamphoto.files.wordpress.com/2014/09/eye-brain-gregory.pdf

Gyasi, G. E. O., Asante, M. M. N., Adans, J., \& Antwi- Boasiako, S. (2018). Assessing food quality delivery in the school feeding programme and its impacts on enrolment: A study of some public basic schools in Bawku Municipality of Ghana. Saudi Journal of Business and Management Studies, 3, 98-106. https://doi.org/10.21276/sjbms.2018.3.1.13

Hussien, H. A., Ibrahim, N. A., \& Hassanin, A. (2015). The Relation Between Nutritional Habits and Social Factors on School Performance of Students of Elementary Schools in Fayoum. Journal of Food and Nutrition Sciences, 3, 71. https://doi.org/10.11648/j.jfns.20150302.17

Ibrahim, H. B. A. (2017). The Role of Schools Feeding Program Supported by DAL Company in Students' Enrolment and Drop-out. Advances in Social Sciences Research Journal, 4(2) 68-74. https://doi.org/10.14738/assrj.42.2517.

Jomaa, L. H., McDonnell, E., \& Probart, C. (2011). School feeding programs in developing countries: impacts on children's health and educational outcomes. Nutrition reviews, 69(2), 83-98. https://doi.org/10.1111/j.1753-4887.2010.00369.x

Just, D. (2014). Three Ways Nutrition Influences Student Learning Potential and School Performance. extension article. Retrieved from https://articles.extension.org/pages /68774/3-ways-nutrition-influences-student-learning-potential-and-school-performance

Kiilu, R. M., \& Mugambi, L. R. (2019). Status of School Feeding Programme Policy Initiatives in Primary Schools in Machakos County, Kenya. African Educational Research Journal, 7, 33-39. https://doi.org/10.30918/aerj.71.18.107

Konzabre, J. G. (2018). The impact of Ghana's school feeding programme on enrollment and retention of pupils in Talensi District in Upper East Region. International Journal of Education, learning and development, 6(6), 69-89.

Kristiansson, E.A., Gelli, A., Welch, V., Greenhalgh, T., Liberato, S., Francis, D. \& Espejo, F. (2016). Costs and cost-outcome of school feeding programmes and feeding programmes for young children. Evidence and recommendations. International Journal of Educational Development, 48, 79-83. https://doi.org/10.1016/j.ijedudev.2015.11.011

Lee, K. (2018). What Is the Importance of Good Nutrition For Kids? Healthy Eating | SF Gate. Retrieved from http://healthyeating.sfgate. com/importance-good-nutrition-kids-6236.html.

Mahama, S. (2017). The Impact of Ghana School Feeding Programme on Female Enrolment, Attendance and Retention in the Wa Municipality of the Upper West Region of Ghana. University for Development Studies, Ghana. Retrieved from http://udsspace.uds.edu.gh/bitstream/123456789/1782/1/THE\%20IMPACT\%20OF\%20GHANA\%20SCHO OL\%20FEEDING\%20PROGRAMME\%20ON.pdf

Maijo, S. N. (2019). Impact of School Feeding Programme on Learners' Academic Performance in Mlunduzi 
Ward, Tanzania. International Journal of Educational Studies, 5(2), 111-114. https://doi.org/10.33687/educ.005.03.2667

McLeod, S. A. (2018). Visual perception theory. Simply Psychology. https://www.simplypsychology.org/perception-theories.html

Mensah, A. O. (2016). Contract Management, Monitoring and Evaluation of Ghana School Feeding Programme at Atwima Kwanwoma District. International Journal of Scientific \& Technology Research, 5, 268-278.

Michelmore, K., \& Dynarski, S. (2017). The Gap Within the Gap: Using Longitudinal Data to Understand Income Differences in Educational Outcomes. AERA Open. https://doi.org/10.1177/2332858417692958

Milledzi, E. Y., Keney, G., \& Amponsah, M. O. (2017). Impact of School Feeding Programme on Access to Basic Education: The Case of South Tongu District of the Volta Region, Ghana. International Journal of Education, 9, 4. https://doi.org/10.5296/ije.v9i4.12124

Milledzi, E.Y., Keney, G., \& Amponsah, M. O. (2017). Impact of school feeding programme on access to basic education: the case of South Tongu District of the Volta Region, Ghana. International Journal of Education, 9(4), 103-117. https://doi.org/10.5296/ije.v9i4.12124

Mkanyika, M. A. (2014). Influence of School Feeding Programme on Pupils Participation in Public Primary Schools in Flood Prone Areas of Garsen Division, Tana Delta District, Kenya (Masters Dissertation of University of Nairobi).

Muiru, A, Thinguri, R, Njagi, A, \& Kiarie, C. W. (2014). Malnutrition: It's Impact on Attendance among Primary School Pupils in Kirie Division, Embu County. Journal of Education and Practice, 5(24), 79-85.

Mwendwa, E., \& Gori, J. (2019). Relationship between School Feeding Programme and the Pupils' Effectiveness in Learning in Public Primary Schools in Kitui County. Scientific Research Journal, 7(7). http://dx.doi.org/10.31364/SCIRJ/v7.i7.2019.P0719667

Mwendwa, E. M., \& Gori, J. M. (2019). Relationship Between School Feeding Programmes and the Pupils' School Attentance in Public Primary Schools in Kitui County, Kenya. International journal for innovation, education and research, 7(10), 1-14. https://doi.org/10.31686/ijier.Vol7.Iss10.1669

National Home Grown School Feeding Programme (NHGSFP). (2017). Retrieved from http://www. actionhealthinc.org/school-feeding-project/.

Ngussa, B. M., \& Mbifile, G. J. (2016). Effect of Food Provision on Pupils' Participation in Learning: A Case Study in Babati Rural District, Tanzania. Saudi Journal of Humanities and Social Sciences, 1(4) 127-136. https://doi.org/ 10.21276/sjhss.2016.1.4.4

Ngussa, B. M., \& Ndiku, L. N. (2014). Constructivism Experiences in Teaching-Learning Transaction among Adventist Secondary Schools in South Nyanza, Tanzania. American Journal of Educational Research, 2(11A), 1-7. https://doi.org/10.12691/education-2-11A-1

Ngussa, B. M., \& Twarira, J. H. (2020). Correlation between Food Provision, Teachers' Involvement and Pupils' Engagement in Learning: A Case of Primary Schools in Arusha City, Tanzania. East African Journal of Education and Social Sciences, 1(1), 1-11. http://dx.doi.org/10.46606/eajess2020v01i01.0001

Nikiema, P. R. (2017). Impact of school feeding programmes on educational outcomes. Evidence from dry cereals in schools in Burkina Faso October 2017. WIDER Working Paper 2017/182. United nations university World institute for Development Economic Research @ wider.unu.edu

Nyakundi, M. E. (2017). Effects of School Feeding Program on Pupils Retention in Public Primary Schools in Dagoratte South-Sub County, Nairobi Country, Unpublished Master Dissertation, Nairobi University. Retrieved from: http://erepository.uonbi.ac.ke/bitstream/ handle/11295/101376

Oganga, B. N. (2013). Feeding Students? Examining Views of Parents, Students and Teachers on the World Food Program's School Feeding Initiatives in Chamwino District in Tanzania. Master's Capstone Projects. 28. Retrieved from https://scholarworks.umass.edu/cie_capstones/28.

Osei-Fosu, A. K. (2011). Evaluating the impact of the capitation grant and the school feeding programme on enrollment, attendance and retention in schools: the case of weweso circuit. Journal of Science and Technology, 31(1), 55. http://dx.doi.org/10.4314/just.v31i1.64886

Phiri, W., \& Chisala, A. (2017). A critical evaluation of the school feeding programme in rural schools: a case of st pauls secondary school kapiri mposh, Zambia. International Journal of Multidisciplinary Research and 
Development. 4(7), 119-123.

Reuben, R. M. (2017). Influence of School Feeding Programme On Participation OfPupils In Public Primary Schools In Kilome Division, Makueni County, Kenya (Unpublished Phd Thesis).

Salifu, I., Boateng, J. K., \& Kunduzore, S. S. (2018). Achieving free compulsory universal basic education through school feeding programme: Evidence from a deprived rural community in northern Ghana, Cogent Education, 5, 1. https://doi.org/10.1080/2331186X.2018.1509429

Sanya, H. (2015). Impact of School Feeding on student attendance in Secondary School: A Case of Kiteto District in Tanzania. Unpublished Master Dissertation, the Open University of Tanzania. Retrieved from: http://repository.out.ac.tz/1466/1/SAN YA-Dissertation.pdf

Serebour, R. (2017). Assessing the Implementation of the Ghana School Feeding Programme (GSFP): A Comparative Case Study of Some Selected Schools in the Atwima Nwbiagya District and Atwima Mponua District of Ghana. University of Bergen, Norway. Retrieved from http://bora.uib.no/bitstream/handle/1956/17422/Rosemond-s-thesis.pdf?sequence=1 and is Allowed=y

Sitao, V. J. R. (2018). An assessment of school feeding programme - pilot phase and its relationship with enrolment, attendance, retention and the local agricultural production in Nampula province in Mozambique. Submitted in fulfilment of the requirement for the degree Doctor of Philosophiae in Public Health Supervisor: Professor Josephine Kiamba, Co-supervisor: Professor Cheryl M E McCrindle. School of Health Systems and Public Health Faculty of Health Sciences University of Pretoria July 2018 (Unpublished PhD dissertation, S28279825).

Snilstveit, B., Stevenson J., Phillips D., Vojtkova, M., \& Gallagher E. (2015). Interventions for Improving Learning Outcomes and Access to Education in Low- and Middle- Income Countries: A Systematic Review." 3ie Systematic Review, 24. London: International Initiative for Impact Evaluation (3ie).

Stuber, N. (2014). Nutrition and Students' Academic Performance at Wilder Research, 651-280-2763. Retrieved from www.wilderresearch.org

Tagoe, I. (2018). The Ghana National School Feeding Program: Peoples' Perceptions about the Program's Impact on School Enrolment, Attendance and Completion. Bowling Green State University, United States. Retrieved 13.10, 2018, from https:/etd.ohiolink.edu/!etd.send_file?accession=bgsu1521682869298246\&disposition=inline

Taylor, A. D., \& Ogbogu, C. O. (2016). The Effects of School Feeding Programme on Enrolment and Performance of Public Elementary School Pupils in Osun State, Nigeria. World Journal of Education, 6(3), 39-47. https://doi.org/10.5430/wje.v6n3p39

Uwameiye, B. E. (2016). Stakeholders Perception on the Impact of the UNICEF Supported School Feeding Programme on Schooling. Asian Journal of Education and E-Learning, 4(2). Retrieved from https://ajouronline.com/index.php/AJEEL/article/view/3642

Uwameiye, B. E., \& Salami, L. I., (2013). Assessment of the Impact of the UNICEF Supported School Feeding Programme on Attendance of Pupils in Federal Capital Territory. International Journal of Academic Research in Progressive Education and Development, 2(1), 209- 218.

World Bank. (2012). System assessment and bench, marking for Education results (SABER). Washington, DC: the world bank. Retrieved from http://go.worldbank.org/NK2EK7MKV0

World Food Programme. (2010). School meals. Available at http://www. wfp.org/schools_meals.

World Food Programme, (2015). School meals and Education. Accessed from documents.wfp.org/stellent/groups/public/

World Food Programme. (2016). School Meals and Education. Factsheet. Retrieved from https://www.wfp.org/school-meals

World Food Program. (2017). Home Grown School Feeding Resources: Framework Synopsis March 2017; REPORT from International Fund for Agricultural Development, World Food Programme, New Partnership for Africa's Development, Food and Agriculture Organization of the United Nations. Retrieved from: https://reliefweb.int/sites/reliefweb.int/files/r esources/wfp290721.pdf

World Food Programme. (2019). The Impact of School Feeding Programmes. Retrieved from Schoolfeeding.osf@wfp.org 
Yendaw, E., \& Dayour, F. (2015). Effect of the National School Feeding Programme on Pupils' Enrolment, Attendance and Retention: A Case Study of Nyoglo of the Savelugu-Nantong Municipality, Ghana. British Journal of Education, Society \& Behavioural Science, 5(3), 341-353. https://doi.org/10.9734/BJESBS/2015/14271.

Yunusa, I. (2012). School Feeding Program in Nigeria: A Vehicle for Nourishment of Pupils. An online journal of the African Educational Research Network, 12(2), 104-110. Retrieved from https://projects.ncsu.edu/aern/TAS12.2/TAS 12.2Yunusa.pdf

\section{Copyrights}

Copyright for this article is retained by the author(s), with first publication rights granted to the journal.

This is an open-access article distributed under the terms and conditions of the Creative Commons Attribution license (http://creativecommons.org/licenses/by/4.0/). 